\title{
MENINGKATKAN KEMAMPUAN PENALARAN MATEMATIS SISWA SMP MELALUI STRATEGI MULTI REPRESENTASI KLASIKAL DAN KELOMPOK KECIL
}

\author{
Nopa Sihombing \\ Guru SMP Advent Pulo Gundur \\ Kabupaten Dairi, Sidikalang, Sumatera Utara \\ nopasihombing32@yahoo.com
}

\begin{abstract}
Abstrak: Tujuan penelitian ini adalah untuk mengetahui peningkatan kemampuan penalaran matematis siswa terkait dengan materi himpunan pada kelas VII SMP. Penelitian ini melibatkan dua kelompok siswa dengan desain komparatif. Sampel dalam penelitian ini adalah siswa kelas VII-A, SMP Perguruan Advent Cimindi, Bandung Barat sebagai kelompok 1 dan siswa kelas VII-A SMPN 1 Parongpong, Bandung Barat sebagai kelompok 2. Kelompok 1 diberi pembelajaran dengan strategi multi representasi klasikal dan kelompok kedua 2 diberi pembelajaran dengan Strategi multi representasi (SMR) dalam kelompok kecil. Hasil penelitian menunjukkan bahwa: (1) terdapat peningkatan kemampuan penalaran siswa setelah diberi pembelajaran srategi multi representasi (SMR) klasikal dan strategi multi representasi (SMR) dalam kelompok kecil, (2) terlihat bahwa strategi multi representasi dapat meningkatkan kemampuan penalaran matematis siswa baik yang diberi perlakuan dengan SMR klasikal maupun yang memperoleh SMR dalam kelompok kecil, dengan demikian strategi multi representasi dipertimbangkan dapat digunakan dalam SMR klasikal maupun SMR dalam kelompok kecil, (3) siswa memberikan respon yang positif terhadap strategi multi representasi klasikal dan strategi multi representasi dalam kelompok kecil.
\end{abstract}

Kata Kunci: Penalaran Matematis, Multi Representasi

Abstract: The purpose of this research is to know the improvement of students' mathematical reasoning ability related to the subject matter in class VII of SMP. The study involved two groups of students with comparative design. The sample in this research is the students of class VII-A, Cimindi Adventist Junior High School, West Bandung as group 1 and students of class VII-A SMPN 1 Parongpong, West Bandung as group 2. Group 1 is given instruction with classical multi-representation strategy and second group 2 given learning with Multirepresentation Strategy (SMR) in small groups. The results showed that: (1) there was an increase in students 'reasoning ability after being given multi-representation (SMR) classical strategy and multi-representation (SMR) strategy in small group, (2) it was seen that multirepresentation strategy could improve students' mathematical reasoning ability were treated with SMR classical as well as those who obtained SMR in small groups, thus multirepresentation strategies were considered to be used in SMR classical as well as SMR in small groups, (3) students positively responded to classical multi-representation strategies and multi-representation strategies in small groups .

Keywords: Mathematical Reasoning, Multi Representation

\section{PENDAHULUAN}

Matematika adalah salah satu mata pelajaran yang penting untuk dipelajari, karena ilmu matematika sering kita gunakan dalam kehidupan sehari-hari contohnya: Ketika melakukan transaksi jual beli digunakan kemampuan menghitung. Untuk mengetahui tinggi pohon dapat menggunakan konsep trigonometri tanpa harus mengukurnya langsung. Pada bidang 
kedokteran, teori peluang digunakan untuk mengetahui suksesnya suatu pengobatan, dan sangat banyak aplikasi langsung yang dapat diambil dari pelajaran matematika dalam menyelesaikan persoalan matematika yang berkaitan dengan kehidupan sehari-hari.

Pentingnya pelajaran matematika dalam kehidupan sehari-hari membuat setiap siswa harus dituntut untuk berfikir kritis, bernalar, kreatif, dan inovatif. Permendiknas No 22 tahun 2006 menyatakan bahwa saat siswa dihadapkan pada persoalan matematis maka siswa harus mampu memberikan alasan secara terorganisasi, menggunakan penalaran pada pola dan sifat, melakukan manipulasi matematika dalam membuat generalisasi, menyusun bukti, atau menjelaskan gagasan dan pernyataan matematika, mejelaskan gagasan serta menghasilkan solusi.

Untuk mewujudkan tujuan tersebut maka salah satu kemampuan matematis yang harus ditingkatkan adalah kemampuan penalaran, karena pada kenyataan dilapangan kemampun penalaran matematis siswa masih rendah disebabkan oleh beberapa fakor yang antar lain: Hasil penelitian Suryadi dalam Hartono (2014) menyatakan bahwa kelemahan siswa masih lemah dalam menemukan pola (bentuk umum) suatu konsep matematika. Siregar (2014) menyatakan bahwa guru asik sendiri menjelaskan apa yang telah disampaikan akibatnya siswa juga belajar sesuai dengan contoh yang diberikan. Sedangkan Rizta \& Hartono (2013) juga menyatakan masih ada siswa tidak mampu mengerjakan soal disebabkan tidak mengerti maksud soal dengan baik.

Sub-sub masalah yang dijawab dalam penelitian ini adalah:

1. Bagaimana kemampuan penalaran matematis siswa yang mendapatkan pembelajaran dengan strategi multi representasi kasikal dan kelompok kecil?

2. Bagaimana peningkatan kemampuan penalaran matematis siswa yang mendapatkan pembelajaran dengan strategi multi representasi kasikal dan kelompok kecil?

3. Bagaimana respon siswa terhadap pembelajaran matematika dan terhadap strategi multi representasi klasikal atau kelompok?

Sesuai dengan permasalahan di atas, tujuan yang dapat diambil dari penelitian ini adalah sebagai berikut:

1. Untuk mengetahui bagaimana kemampuan penalaran matematis siswa yang mendapatkan pembelajaran strategi multi representasi klasikal dan kelompok kecil.

2. Untuk mengetahui bagaimana respon siswa terhadap pembelajaran matematika dan terhadap model pembelajaran strategi multi representasi klasikal dan kelompok kecil. 


\section{KAJIAN PUSTAKA}

Kemampuan penalaran adalah proses berfikir untuk menghasilkan sejumlah konsep dan pengertian. Ratna Sariningsih (2014) menyatakan kemampuan penalaran adalah kemampuan untuk menemukan penyelesaian, kemampuan untuk menarik kesimpulan suatu pertanyaan dan melihat hubungan implikasi serta emampuan untuk melihat hubungan antara idea-idea. Penalaran sangatlah dibutuhkan oleh setiap orang untuk menarik kesimpulan dari kasus yang bersifat individual menjadi kasus yang bersifat umum dan sebaliknya dari kasus- kasus yang bersifat umum menjadi individual. (Bernard, 2014).

Penalaran matematika merupakan kemampuan dalam suatu penarikan kesimpulan dengan cara berfikir logis dan mampu memperlihatkan hubungan antar dua hal atau lebih serta mampu menyelesaikan masalah dan menjelaskan setiap alasan dari penyelesaian masalah tersebut. Oleh karena itu kemampuan penalaran sangat penting untuk dimiliki oleh setiap siswa.

Indikator penalaran dalam penelitian ini yang telah dirangkum dalam Peraturan Dirjen Dikdasmen No. 506/C/PP/2004 (Kurniasari \& Susanah, 2013) dan Sri Wardani (2008). Penalaran yang harus dicapai oleh siswa yaitu:

1. Mampu menyajikan pernyataan matematika secara lisan, tulisan, diagram dan bentuk aljabar.

2. Memeriksa kesasihan suatu argumen.

3. Menarik kesimpulan, menyusun bukti, memberi alasan terhadap kebenaran solusi.

4. Mampu membuat kesimpulan dari pernyataan.

Multi representasi pertama dikembangkan oleh ahli dan pemula fisikawan dalam Patterns of Multiple Representation Use by Experts and Novices during Physics Problem Solving karya Kohl et al. (2008) Physics Education Research (PER) mewawancarai ahli fisikawan dan pemula. (PER) memberikan dua tipe soal multi representasi yang sudah disediakan untuk mereka dan di mana siswa harus mengkonstruksik representasi sendiri.

Strategi multi representasi yang akan digunakan dalam penelitian ini yaitu menggunakan Gambar, diagram, simbol, tabel, rumus, kata-kata dan gerakan. Hudiono (2010) menyatakan strategi multi representasi klasikal akan menghasilkan kemampuan matematik lebih baik pada siswa dengan tingkat kemampuan sedang atau rendah. Karena dengan adanya pengajaran dan LKS dalam konsep multi representasi serta membimbing siswa akan membuat siswa lebih berusaha untuk memecahkan persoalan matematis.

Adapun kegiatan langkah-langkah yang dilakukan dalam strategi multi representasi klasikal yang telah dirangkum dalam (Hudiono, 2010) adalah:

1. Guru menjelaskan materi.

2. Guru memberikan LKS.

3. Siswa memahami soal yang diberikan berupa apa yang diketahui dan apa yang ditanya.

4. Mengajukan pertayaan arahan, hingga siswa dapat memahami masalah dengan benar. 
5. Siswa memilih alternatif (kata-kata, gambar, diagram, garis bilangan, rumus, tabel,) untuk memecahkan masalah.

6. Guru memantau kegiatan pembelajaran dan memberikan bimbingan kepada siswa yang mengalami kesulitan.

7. Jika masih ada waktu guru meminta beberapa siswa untuk mempresentasikan temuan mereka.

Strategi multi representasi dalam kelompok kecil adalah proses pembelajaran yang sangat baik untuk dilakukan, karena siswa mereka akan menyadari bahwa mereka adalah sebuah tim yang mempunyai tujuan bersama yang harus dicapai.

Menurut Iskandar (Stephanus, 2014) ada beberapa hal yang harus diperhatikan dalam pembagian kelompok kecil yaitu:

a. Harus memperhatikan keheterogenan (secara akademis maupun jenis kelamin) siswa dikelompokkan menjadi tiga jenis kemampuan akademis yang berbeda. Dalam setiap kelompok terdapat terdiri atas satu orang yang berkemampuan tinggi, satu orang yang berkemampuan sedang dan satu orang yang berkemampuan rendah, dapat dilihat dari pencapaian nilai.

b. Jika jumlah peserta kelas sangat besar, sebaiknya dibagi dalam kelompok kecil beranggotakan 4 atau 5 orang sejalan dengan pendapat Hutagaol (2013) menyatakan bahwa siswa dibagi dalam kelompok kecil untuk saling bekerja sama dalam suatu tugas untuk mencapai tujuan bersama, dan setiap kelompok belajar terdistribusi secara heterogen dengan tujuan bahwa siswa yang pandai dapat membantu atau membimbing siswa yang lemah, sehingga dapat terjadi kolaborasi antar siswa maupun antar kelompok serta Majid \& Rochman (2014) yang menyatakan bahwa "Aktivitas pembelajaran kelompok dapat memperluas perspektif dan dapat membangun kecakapan interpersonal untuk berhubungan dengan orang lain."

Adapun langkah-langkah kegiatan yang dilakukan pada multi representasi kelompok kecil, yang telah dirangkum dalam Sahyudin (2014) yaitu:

1. Siswa membentuk kelompok yang terdiri dari 4 orang.

2. Guru menjelaskan materi

3. Guru memberikan LKS kepada setiap siswa

4. Memahami soal atau kondisi yang diberikan kepada siswa, yang berupa apa yang diketahui, apa yang tidak diketahui, apa yang ditanyakan,

5. Siswa menganalisis informasi yang ada, berdiskusi dan melaksanakan rencana untuk mencari solusi.

6. Mengembangkan pemikiran kritis dan keterampilan kreatif, membentuk hipotesis yang dalam hal ini berupa dugaan jawaban.

7. Siswa memilih strategi (kata-kata, diagram, gambar, garis bilangan, rumus, tabel) untuk memecahkan masalah, mengumpulkan data dan menganalisis.

8. Berkomunikasi dengan guru dan teman kelompok atas temuan, mengenai solusi masalah. 
9. Setelah itu siswa memecahkan masalah dan jika ada waktu mempresentasikan hasil diskusi mereka di depan kelas.

\section{METODE PENELITIAN}

Metode penelitian yang digunakan adalah penelitian komperatif. Penelitian komparatif merupakan jenis penelitian yang digunakan untuk membandingkan antara dua kelompok atau lebih dari suatu variabel, (Fraenkel \& Wallen, 2006).Populasi dalam penelitian ini adalah seluruh siswa SMP di Bandung Barat, dan yang menjadi sampel adalah siswa kelas VII-A di Perguruan Advent Cimindi yang mendapatkan strategi multi representasi klasikal dan siswa kelas VII-A di SMPN 1 Parongpong yang mendapatkan strategi multi representasi dalam kelompok kecil.

Populasi dalam penelitian ini adalah seluruh siswa SMP di Bandung Barat, dan yang menjadi sampel adalah siswa kelas VII-A di Perguruan Advent Cimindi yang mendapatkan strategi multi representasi klasikal dan siswa kelas VII-A di SMPN 1 Parongpong yang mendapatkan strategi multi representasi dalam kelompok kecil.

Prosedur penelitian dalam penelitian ini tersaji pada bagan berikut:

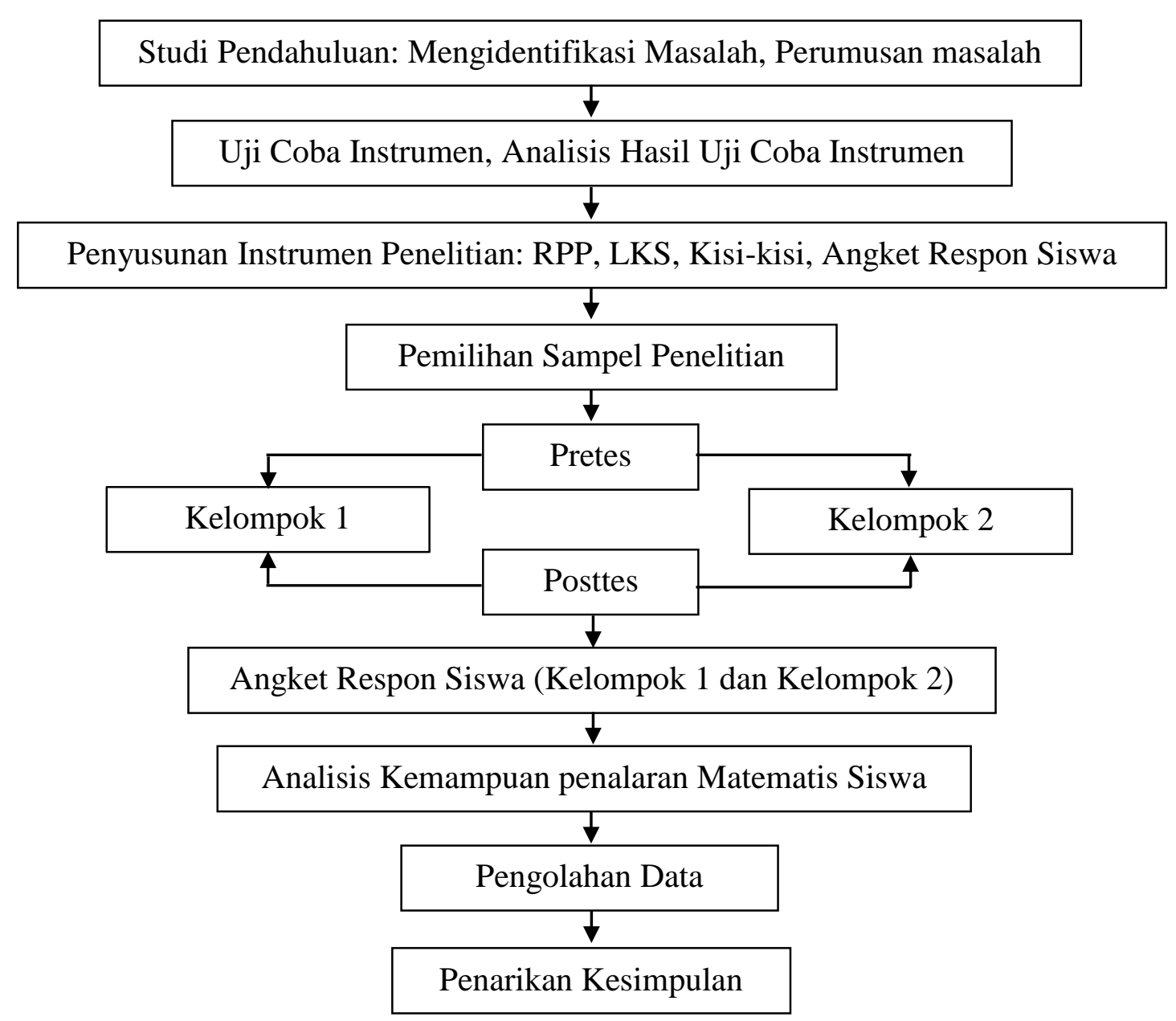




\section{HASIL PENELITIAN DAN PEMBAHASAN}

Sebelum siswa diberikan pembelajaran dengan SMR klasikal dan SMR dalam kelompok kecil, terlebih dahulu dilakukan pretest untuk mengetahui kemampuan penalaran matematis siswa sebelum memperoleh pembelajaran dengan SMR klasikal dan kelompok kecil. Untuk melihat apakah terdapat perbedaan yang signifikan pada kemampuan awal matematis siswa maka dilakukan uji beda dua rata-rata.

Sebelum dilakukan uji beda dua rata-rata terlebih dahulu peneliti melakukan uji normalitas dan uji homogenitas. Untuk uji normalitas digunakan uji Shapiro Wilk sedangkan untuk uji homogenitas digunakan uji Levene. Dari uji normalitas disimpulkan bahwa data kelompok SMR klasikal dan kelompok kecil berasal dari populasi yang tidak berdistribusi normal, sedangkan dari hasil uji homogentitas pretest disimpulkan bahwa varians data populasi kelompok SMR klasikal dan kelompok kecil tidak memiliki varians homogen yang sama. Karena data tidak berdistribusi normal, maka untuk uji beda dua rata-rata digunakan uji U Mann-Withney. Dapat dilihat pada Tabel 1.

Tabel 1. Statistik Mann Whitney

\begin{tabular}{|l|l|}
\hline & Gain \\
\hline Mann-Whitney U & 370,000 \\
Wilcoxon W & 1,190 \\
Z & $-1,594$ \\
Asymp. Sig. (2-tailed) & 0,111 \\
\hline
\end{tabular}

Berdasarkan Tabel $1 \mathrm{di}$ atas,menunjukan hasil sig. $(2$-tailed $)=0,011>0,05$, maka Ho tidak ditolak. Artinya: Tidak terdapat perbedaan yang signifikan pada peningkatan kemampuan penalaran siswa sebelum memperoleh strategi multi representasi klasikal dan kelompok kecil.

Peningkatan kemampuan penalaran matematis siswa untuk kedua kelompok siswa yang memperoleh SMR klasikal dan kelompok kecil dapat dilihat pada Tabel 2.

Tabel 2. Kemampuan Penalaran Matematis siswa

\begin{tabular}{|l|l|l|c|l|c|c|c|}
\hline Pembelajaran & N & \multicolumn{2}{l|}{ Pretest } & \multicolumn{2}{l|}{ Posttest } & \multicolumn{2}{l|}{ Gain Ternormalisasi } \\
\hline & & S & $\bar{x}$ & S & $\bar{x}$ & S & $\bar{x}$ \\
\hline SMR klasikal & 24 & 1,94 & 2,88 & 2,33 & 22,96 & 0,09 & 0,80 \\
\hline $\begin{array}{l}\text { SMR dalam } \\
\text { kelompok } \\
\text { kecil }\end{array}$ & 40 & 0,94 & 1,93 & 3,49 & 21,58 & 0,14 & 0,76 \\
\hline
\end{tabular}

Berdasarkan Tabel 4.1. Kemampuan penalaran matematis siswa sebelum memperoleh SMR klasikal dan kelompok kecil masih rendah, dilihat dari skor maksimum ideal (SMI=28). Skor rata-rata posttest kemampuan penalaran matematis siswa yang memperoleh pembelajaran SMR klasikal lebih baik dari skor rata-rata posttest siswa yang memperoleh SMR dalam 
kelompok kecil. Rata-rata skor gain ternormalisasi kemampuan penalaran matematis siswa yang memperoleh SMR klasikal adalah 0,80, sedangkan skor gain ternormalisasi SMR dalam kelompok kecil adalah 0,76 . Hal ini menunjukkan bahwa peningkatan kemampuan penalaran matematis siswa pada kedua kelompok tergolong tinggi dilihat dari indeks gain $G \geq$ 0,70. Sebaran data gain ternormalisasi yang memperoleh SMR klasikal lebih mendekati ratarata dibandingkan siswa yang memperoleh SMR dalam kelompok kecil.

Berdasarkan uji normalitas terhadap data gain ternormalisasi kemampuan penalaran matematis siswa, disimpulkan bahwa data siswa yang memperoleh SMR klasikal berasal dari populasi yang berdistribusi normal, sedangkan siswa yang memperoleh pembelajaran SMR dalam kelompok kecil data berasal dari populasi yang tidak berdistribusi normal. Pada uji homogenitas data gain ternormalisasi kemampuan penalaran matematis siswa disimpulkan bahwa varians populasi data tidak memiliki varians homogen yang sama.

Untuk melihat apakah terdapat perbedaan yang signifikan pada peningkatan kemampuan penalaran matematis siswa maka dilakukan uji Mann Whitney, ditunjukkan pada Tabel 3 berikut:

Tabel 3. Statistik Mann-Whitney uji Beda Dua Rata-Rata Gain Ternormalisasi

\begin{tabular}{|l|c|}
\hline & Gain \\
\hline Mann-Whitney U & 409,500 \\
Wilcoxon W & 1,230 \\
Z & $-0,978$ \\
Asymp. Sig. (2-tailed) & 0,328 \\
\hline
\end{tabular}

Berdasarkan Tabel 3 Signifikansi (2-tailed.) $=0,328>0.05$ maka $H_{0}$ tidak ditolak. Artinya: Tidak terdapat perbedaan yang signifikan pada peningkatan kemampuan penalaran matematis siswa yang memperoleh SMR klasikal dan siswa yang memperoleh SMR dalam kelompok kecil.

Rata-rata skor respon siswa terhadap pembelajaran matematika yang memperoleh SMR klasikal yaitu 3,01 lebih dari skor respon netral yaitu 2,5, artinya siswa memberikan respon yang positif terhadap pembelajaran matematika. Rata-rata skor respon siswa terhadap pembelajaran matematika yang memperoleh SMR dalam kelompok kecil yaitu 3,09 lebih dari rata-rata skor respon netral yaitu 2,5, artinya siswa memberikan respon yang positif terhadap pembelajaran matematika. Sedangkan untuk skor rata-rata siswa terhadap SMR klasikal yaitu 3,05 , lebih besar dari skor respon netral yaitu 2,5. Artinya siswa juga memberikan respon yang positif terhadap SMR klasikal. Rata-rata skor respon siswa terhadap strategi pembelajaran SMR dalam kelompok kecil yaitu 3,11, lebih besar dari skor rata-rata respon netral, artinya siswa memberikan respon yang positif terhadap SMR dalam kelompok kecil. 
Hasil uji beda dua rata-rata menunjukkan bahwa tidak terdapat perbedaan yang signifikan pada kelompok yang memperoleh pembelajaran dengan SMR klasikal dan SMR dalam kelompok kecil. Namun jika dilihat dari rata-rata skor respon siswa terhadap pembelajaran matematika yang memperoleh SMR dalam kelompok kecil yaitu 3,09 lebih baik dari rata-rata skor respon siswa terhadap pembelajaran matematika yang memperoleh SMR klasikal yaitu 3,01 .

Hasil respon siswa terhadap pembelajaran matematika yang mendapat pembelajaran SMR dalam kelompok kecil pada pernyataan nomor 5 yang berbunyi "Materi matematika sangat menarik untuk dipelajari” terdapat 55\% menjawab setuju dan 30\% menjawab sangat setuju dan pernyataan nomor 4 yang berbunyi "Hubungan antara materi pembelajaran matematika dengan kehidupan sehari-hari terlihat jelas bagi saya" $90 \%$ menjawab setuju dan $5 \%$ menjawab sangat tidak setuju yang artinya bahwa mereka sangat tertarik dengan pelajaran matematika dan menyadari bahwa materi matematika sangat berguna bagi kehidupan seharihari. Sedangkan hasil respon siswa terhadap pembelajaran matematika yang mendapatkan SMR klasikal pada pernyataan no 4 terdapat $66,6 \%$ menjawab setuju dan $16,7 \%$ menjawab sangat setuju artinya mereka menyadari bahwa matematika sangat penting bagi kehidupan mereka. Pada pernyataan no 5, terdapat $62,5 \%$ menjawab setuju dan $8,3 \%$ menjawab sangat setuju yang artinya bahwa mereka tertarik pada pembelajaran matematika.

Rata-rata skor respon siswa terhadap strategi pembelajaran juga menunjukkan bahwa SMR dalam kelompok kecil lebih baik dari SMR klasikal, dilihat dari skor rata-rata siswa yaitu, skor rata-rata siswa terhadap SMR dalam kelompok kecil 3,11 lebih besar dari skor siswa yang memperoleh SMR klasikal yaitu 3,05. Dilihat dari hasil respon siswa yang memperoleh pembelajaran SMR dalam kelompok kecil, pada pernyataan nomor 12 yang bunyinya "Gambar, diagram simbol, rumus, kata-kata dan gerakan membuat saya lebih mudah mengerti materi himpunan." Terdapat $60 \%$ menjawab setuju dan 35\% menjawab sangat setuju artinya mereka sangat suka dengan SMR. Pada pernyataan 18 yang berbunyi, "Saya senang belajar berkelompok karena saya bisa berdiskusi dengan teman kelompok saya jika tidak mengerti”, terdapat 55\% menjawab setuju dan $40 \%$ menjawab sangat setuju artinya bahwa, mereka sangat suka belajar berkelompok. Sedangkan hasil respon siswa pada pernyataan negatif nomor 18 yang berbunyi bawha "Saya senang belajar secara klasikal dikelas karena saya bisa lebih konsentrasi belajar dan menjawab soal", terdapat 62,5\% menjawab setuju $25 \%$ menjawab sangat setuju yang artinya bahwa mereka senang belajar secara klasikal. Sedangkan respon siswa yang memperoleh SMR klasikal pada pernyataan no 12 terdapat 50\% menjawab setuju 
dan $25 \%$ menjawab sangat setuju yang artinya bahwa siswa setuju pembelajaran strategi multi representasi dapat meningkatkan kemampuan penalara matematis siswa.

\section{KESIMPULAN DAN SARAN}

Dari hasil pembahasan dapat ditarik kesimpulan yaitu: (1) Kemampuan penalaran matematis siswa menunjukkan peningkatan, baik pada siswa yang memperoleh SMR klasikal maupun siswa yang memperoleh SMR dalam kelompok kecil. Nilai rata-rata kemampuan penalaran matematis awal untuk siswa yang diberi perlakuan dengan SMR klasikal adalah $10,28 \%$ dan rata-rata akhirnya adalah $82 \%$ sedangkan gain yang diperoleh adalah 0,80 termasuk dalam ketegori tinggi. Sedangkan nilai rata-rata kemampuan penalaran matematis awal untuk siswa yang memperoleh SMR dalam kelompok kecil adalah 6,89\% dan rata-rata akhirnya adalah 77,05\%, sedangkan gain yang diperoleh adalah 0,76 termasuk dalam ketegori tinggi. (2) Terlihat bahwa strategi multi representasi dapat meningkatkan kemampuan penalaran matematis siswa baik yang diberi perlakuan dengan SMR klasikal maupun yang memperoleh SMR dalam kelompok kecil, dengan demikian strategi multi representasi dapat digunakan dalam SMR klasikal maupun SMR dalam kelompok kecil. (3) Siswa memberikan respon yang positif terhadap pembelajaran matematika dan terhadap strategi multi representasi klasikal dan kelompok kecil.

Berdasarkan hasil penelitian dan kesimpulan yang diperoleh, maka penulis memberikan beberapa saran kepada pembaca untuk kebaikan dalam penelitian selanjutnya:

1. Dari kesimpulan yang telah diuraikan di atas maka SMR klasikal maupun dalam kelompok kecil dapat dijadikan sebagai alternatif strategi pembelajaran yang dapat digunakan di kelas.

2. Dalam melakukan suatu penelitian studi komparatif, guru/peneliti harus benar-benar memahami/mengerti kedua strategi atau model pembelajaran yang akan diimplementasikan agar hasilnya sesuai dengan prosedur yang seharusnya.

3. Dalam penggunaan strategi multi representasi dalam kelompok kecil guru/peneliti harus lebih memperhatikan siswa saat belajar kelompok dan melihat apakah terdapat siswa yang tidak mau berdiskusi atau hanya belajar sendiri.

\section{DAFTAR PUSTAKA}

Bernard, Martin. (2014). Pengaruh Pembelajaran Dengan Menggunakan Multimedia Macromedia Falsh Terhadap Kemampuan Penalaran Matematik. Prosiding Seminar Nasional Pendidikan Matematika. Volume 1, ISSN 2355-0473, 425 
Fraenkel, J., \& Wallen, N. E. (2006). How to Design and Evalute Research in Education. Sixth Edition. New York: Mc- Grawhil. Tersedia: Download Pdf doha.ac.mu/.../Research\%20Methods/DesigningAndEvaluatingResearch: 4 Mei 2015

Hutagaol, K. (2013). Pembelajaran kontekstual untuk meningkatkan kemampuan representasi matematis siswa sekolah menengah pertama. Infinity Journal, 2(1), 85-99.

Hartono, 2. (2014). Peningkatan Kemampuan Pemecahan Masalah dan Penalaran Matematis Melalui Pendekatan Matematika Realistik Pada Siswa Kelas VII SMPNI Hinar Kabupaten Langkat . Tesis. Universitas Negeri Medan

Kurniasari, Y., \& Susanah. (2013). Penerapan Teknik Probing Promting Untuk Mengetahui Kemampuan Penalaran MatematikaSiswa Kelas 7 G di SMPN 1 REJOSO. Jurnal Online Universitas Negeri Surabaya, 3.

Majid, A., \& Rochman, C. (2014). Pendekatan Ilmiah dalam Implementasi kurikulum 2013. Bandung: PT Remaja Rosdakarya

Ratna Sariningsih. (2014). Peningkatan Kemampuan Penalaran Matematika Siswa SMA Menggunakan Pembelajaran Kontekstual. Prosiding Seminar Nasional Pendidikan Matematika. Volume 1, ISSN 2355-0473, 214.

Rizta,A., \& Hartono,Y. (2013). Pengembangan soal Penalaran Model TIMMS Matematika SMP. JURNAL KREANO, ISSN : 2086-2334, 2.

Peraturan Menteri Pendidikan Nasional No. 22 Tahun 2006 tanggal 23 Mei 2006 tentang Standar Isi.

Sahyudin. (2014). Meningkatkan Kemampuan Pemecahan Masalah Matematis Dan Berpikir Kreatif Siswa Melalui Model Pembelajaran Diskursus Multi Representasi (DMR). Tesis Universitas Pendidikan Indonesia Bandung, 95.

Siregar, R. H. (2014). Peningkatan Kemampuan Penalaran Formal Matematis Dan Sikap Siswa Terhadap Matematika Melalui Pembelajaran Berbasis Masalah di YPI SMP Hikmatul Fadilalah Medan . TESIS . Universitas Negeri Medan

Slavin, R.E. (2005). Cooperative Learning. Bandung: Nusa Media

Stepanus, O. (2015). Implementasi Model Pembelajaran Conceptual Understanding Procedures Cups Berbantu Maple dan Kooperatif Tipe Learning Together (LT) Berbantu Maple Terhadap Kemampuan Pemecahan Konsep Matematis Siswa 